\title{
Profil Pengembangan Usaha Ternak Sapi Perah di Luar Jawa (Kasus Dataran Tinggi Kota Padang Panjang, Sumatera Barat)
}

\section{(Dairy Farm Business Development in Outside Java Profile (Case of Highland of Padang Panjang City, West Sumatera))}

\author{
Priyanto D, Herawati T \\ Balai Penelitian Ternak, PO Box 221, Ciawi, Bogor 16002 \\ dwipriyanto43@yahoo.co.id
}

\begin{abstract}
National demand for milk products is still unfulfilled, so that it has to be imported. This is because the dairy cattle business is still predominantly done by tradistional farm, so productivity is still not optimal. Research on the business profile of dairy cattle conducted in the highlands (Padang Panjang regency) as a part of policy development in outside Java Island. The results showed that, the potential of land resources and climatic conditions of the locations has a positive prospect in the development of dairy cattle (cold climate and the carrying capacity of forage is available). Dairy cattle maintenance is performed in groups (communal stables). Forage grass is a main source which come from forest land, while the superior grass is only for additional. Supplement feed in the form of concentrate is still difficult to obtain continuously and the price is still high. Additional tofu by product is a major additional feed. Analysis results "Typology of Business" showed that the proportion of contributions from dairy cattle business results reached 24.93 percent (occupied third portion), lower than vegetables farming, and as an agricultural laborer. Vegetable crops is a seed plant that has the largest portion in community farming, and the region of West Sumatra is a supplier vegetables to other provinces. Milk marketing channels varies, namely the dominant undertaken to supply cafes, dairy traders, and sent to other areas (Riau and Padang Regency), and send to the "Milk House". Marketing problems are still being felt especially during the fasting month (Cafes are closed), so it is often a case of discarded milk is very detrimental to farmers, and there are restrictions on milk production by reducing feeding (concentrates), to avoid excess production of milk.
\end{abstract}

Key Words: Business Profile, Dairy Cattle, West Sumatra

\begin{abstract}
ABSTRAK
Permintaan produk susu secara nasional masih belum terpenuhi, sehingga masih dilakukan impor. Hal tersebut karena usaha ternak sapi perah masih dominan dilakukan oleh peternakan rakyat sehingga produtivitas masih belum optimal. Penelitian tentang profil usaha ternak sapi perah dilakukan di dataran tinggi (Kota Padang Panjang) sebagai langkah kebijakan prospek pengembangan di luar Pulau Jawa. Hasil penelitian menunjukkan bahwa, potensi sumber daya lahan dan kondisi iklim di lokasi memiliki prospek positif dalam pengembangan sapi perah (iklim dingin dan daya dukung pakan hijauan tersedia). Pemeliharaan masih dilakukan secara kelompok (kandang komunal). Pakan hijauan pendukung utama adalah rumput lapangan bersumber dari lahan kehutanan, sedangkan rumput unggul hanya sebagai tambahan. Pakan penguat berupa konsentrat masih sulit diperoleh secara kontinyu dengan harga mahal. Ampas tahu merupakan pakan tambahan utama. Hasil analisis Tipologi Usaha terlihat bahwa proporsi sumbangan hasil usaha ternak sapi perah mencapai 24,93\% (menduduki porsi ke-3), setelah usaha tani sayuran, dan sebagai buruh tani. Komoditas tanaman sayuran adalah tanaman unggulan yang memiliki sumbangan terbesar masyarakat, dan wilayah Sumbar sebagai penyuplai sayuran ke provinsi lainnya. Jalur pemasaran susu cukup bervariasi, yakni dominan dilakukan untuk mensuplai cafecafe, pedagang olahan susu, dan dikirim ke wilayah lainnya (Riau dan Kota Padang), maupun disetor ke "Rumah Susu". Permasalahan pemasaran masih dirasakan khususnya pada saat bulan
\end{abstract}


puasa (cafe-cafe tutup), sehingga sering terjadi kasus susu dibuang yang sangat merugikan peternak, serta cenderung ada pembatasan produksi susu dengan mengurangi pemberian pakan (konsentrat), agar tidak terjadi kelebihan produksi susu.

Kata Kunci: Profil Usaha, Sapi Perah, Sumatera Barat

\section{PENDAHULUAN}

Produksi susu nasional selama ini masih belum mampu memenuhi kebutuhan, sehingga masih dilakukan impor susu bubuk yang mencapai $70 \%$ dari kebutuhan (Deny 2014). Usaha ternak sapi perah di Indonesia masih tertumpu pada usaha peternakan rakyat, yang sistem manajemen pemeliharaan masih mengandalkan potensi sumber daya yang ada sehingga tingkat produktivitas masih rendah dan pendapatan yang dihasilkan belum optimal. Kondisi tersebut terjadi karena ketidakseimbangan antara kemampuan produksi susu nasional dibandingkan dengan permintaan konsumen. Produksi susu nasional pada tahun 2005 mencapai rataan 485.717 ton/tahun, sedangkan permintaan konsumen susu pada periode tersebut sudah mencapai rataan 1.921 .383 ton/tahun, sehingga mampu memasok kebutuhan nasional 25,27\% (Ditjen Peternakan 2006). Pada tahun 2016 produksi susu dalam negeri sebesar 787.000 ton sedangkan kebutuhan konsumi mencapai 4.200.000 ton, yang hanya mencapai 18,7\% kebutuhan nasional (Tempo 2016), yang hal tersebut cenderung mengalami penurunan sehingga kebutuhan impor susu semakin meningkat.

Untuk mengantisipasi kesenjangan yang semakin melebar antara produksi susu nasional dengan permintaan konsumen pada tahun ke depan perlu dilakukan upaya dalam peningkatan produksi susu nasional. Hal tersebut merupakan peluang yang terbuka luas bagi pengembangan peternakan sapi perah yang mengarah pada usaha agribisnis sapi perah. Upaya tersebut harus berkonsep agribisnis yang berprinsip dasar merobah keunggulan komparatif (comparative advantage) menjadi keunggulan bersaing (competitive advantage), dimana harus ditangani dari sektor hulu sampai hilir, dan yang diutamakan adalah melalui pemberdayaan ekonomi rakyat (Saragih 2001). Fungsi-fungsi agribisnis terdiri atas kegiatan pengadaan dan penyaluran sarana produksi, kegiatan produksi primer (budidaya), pengolahan (agro-industri), dan pemasaran. Fungsi-fungsi tersebut kemudian disusun menjadi suatu sistem, dimana fungsi-fungsi tadi menjadi subsistem dari sistem agribisnis (Sa'id \& Intan 2001). Lebih lanjut ditegaskan bahwa saat ini usaha peternakan sudah harus memasuki industri pertanian yang berbasis peternakan dan subsektor peternakan ditargetkan sebagai pendukung utama sektor pertanian. Pembangunan tersebut harus tetap diarahkan untuk meningkatkan pendapatan petani peternak, mendorong diversifikasi pangan, perbaikan mutu gizi masyarakat, dan mengembangkan ekspor (Pambudi et. al. 2001).

Ditinjau dari distribusi penyebaran populasi sapi perah di Indonesia, penyebaran populasi masih tertumpu di wilayah Pulau Jawa, yakni mencapai 402.130 ekor $(98,62 \%)$, di Pulau Sumatera 3.450 ekor $(0,84 \%)$, serta wilayah lainnya 2.157 ekor $(0,54 \%)$ (Gayatri et.al. 2005). Kondisi demikian merupakan pertimbangan dalam rekomendasi kebijakan pengembangan sapi perah di luar Pulau Jawa, dalam mendukung kebutuhan susu nasional dan mengurangi impor dari luar. Prospek daya dukung wilayah (lahan usaha) di luar Pulau Jawa masih tersedia luas sehingga dapat memberikan kontribusi yang besar dalam pengembangan usaha peternakan termasuk sapi perah. Ditinjau dari ketersediaan SDM peternak masih diklasifikasikan rendah, sehingga masih perlu difasilitasi melalui pembinaan kelembagaan yang disertai pendampingan teknologi agar usaha ternak yang dilakukan dapat lebih memberikan keuntungan. Penelitian ini bertujuan untuk mengkaji prospek kelayakan pengembangan sapi perah di lokasi dataran tinggi luar Pulau Jawa, yakni 
di kota Padang Panjang dilihat dari kinerja pengembangannya dalam rekomendasi peningkatan produktivitas usaha ternak sapi perah mendukung pendapatan peternak.

\section{MATERI DAN METODE}

Penelitian tentang analisis agro-ekosistem dan profil usaha ternak sapi perah dilakukan di lokasi pengembangan sapi perah di dataran tinggi Kota Padang Panjang. Lokasi terpilih adalah merupakan wilayah pengembangan yang telah dilakukan oleh Ditjen PKH melalui pengembangan bibit sapi perah dengan status populasi yang tinggi. Tahapan metode penelitian yang dilakukan meliputi langkah-langkah sebagai berikut:

1. Desk Study dengan melakukan analisis data sekunder dan informasi penentu kebijakan dalam program pengembangan usaha ternak sapi perah di Indonesia, yang salah satunya dalam rekomendasi menentukan lokasi penelitian di luar Jawa.

2. Melakukan pendekatan Participatory Rural Appraisal (PRA) melalui diskusi kelompok dan observasi lapang di lokasi pengamatan (Gibbs 1985) dan dilakukan analisis "Agroekosistem" sebagai langkah rekomendasi ketepatan dalam analisis potensi sumberdaya lahan dalam prospek pengembangan sapi perah spesifik lokasi (Conway 1985).

3. Melakukan survei terstruktur dengan mengisi kuesioner tentang profil usaha ternak serta menganalisis ekonomi kelayakan usaha ternak. Melalui kegiatan tersebut dapat digambarkan profil usaha ternak sapi perah di lokasi, serta dapat direkomendasikan kebutuhan teknologi dan model kelembagaan dalam mamperbaiki kinerja usaha ternak.

4. Analisis yang dilakukan adalah analisis Tipologi Usaha (Soehadji 1992), dan analisis ekonomi usaha ternak berdasarkan petunjuk (Amir \& Knipcheer 1989) yang digunakan sebagai data dasar sebelum dilakukan penerapan model pengembangan (sebagai data ex-ante analysis).

Rekomendasi kebijakan pengembangan usaha ternak sapi perah di luar Jawa merupakan alternatif dalam mendukung keberhasilan program swasembada susu nasional yang masih jauh dari capaian.

\section{HASIL DAN PEMBAHASAN}

\section{Perkembangan populasi sapi perah nasional dan regional kepulauan}

Ditjen PKH telah banyak melakukan pengembangan ternak sapi perah di 25 Provinsi luar Pulau Jawa, tetapi sebarannya masih relatif kecil dan tidak merata. Dilihat dari perkembangan populasi ternak yang ada terlihat bahwa pada dekade 4 tahun terakhir (2012-2015) setiap tahun selalu dikembangkan di beberapa provinsi, tetapi posisi populasi sapi perah secara umum mengalami penurunan $15,85 \%$. Apabila dikelompokkan pada wilayah kepulauan terlihat hanya di Pulau Sumatera yang mengalami peningkatan walau relatif kecil $(2,61 \%)$ (Tabel 1). Sedangkan di lokasi lainnya termasuk di Pulau Jawa menurun tajam (Gambar 1). Berdasarkan kondisi demikian diperlukan kebijakan baik oleh pemerintah Pusat maupun regional agar target swasembada susu dapat dicapai, walaupun dalam jangka panjang.

Dilihat perkembangan populasi sapi perah dari tahun 2011-2015 menunjukkan bahwa yang mengalami peningkatan populasi hanya di Pulau Sumatera mencapai 399 ekor (meningkat 16,74\%), sedangkan di lokasi pulau lainnya mengalami penurunan termasuk di Jawa menurun 16,01\%, di Bali/NTT menurun 24,86\%, bahkan di Papua habis sama sekali. Kondisi demikian menggambarkan bahwa terjadi penurunan populasi total populasi 
nasional hingga $15,85 \%$. Oleh karena itu perlu dilakukan model pengembangan yang tepat agar populasi sapi perah meningkat di wilayah pengembangan maupun di lokasi lainnya.

Tabel 1. Perkembangan populasi ternak sapi perah di wilayah kepulauan di Indonesia

\begin{tabular}{|c|c|c|c|c|}
\hline \multirow{2}{*}{ Lokasi/pulau } & \multicolumn{2}{|c|}{ Tahun } & \multirow{2}{*}{$\begin{array}{c}\text { Penurunan } \\
\text { (ekor) }\end{array}$} & \multirow{2}{*}{$\%$} \\
\hline & 2011 & 2015 & & \\
\hline Sumatera & 2.383 & 2.782 & +399 & 16,74 \\
\hline Jawa & 592.520 & 497.616 & -94.904 & $-16,01$ \\
\hline Bali/Nusa Tenggara & 189 & 142 & -47 & $-24,86$ \\
\hline Kalimantan & 387 & 360 & -27 & $-6,97$ \\
\hline Sulawesi & 1.741 & 1.619 & -122 & $-7,01$ \\
\hline Papua & 11 & 0 & -11 & $-100,00$ \\
\hline Total & 597.231 & 502.519 & -94.712 & $-15,85$ \\
\hline
\end{tabular}

Sumber: Ditjen PKH (2015)

\section{Program dan kebijakan pengembangan sapi perah di Provinsi Sumatera Barat}

Provinsi sumatera Barat (Sumbar) secara administratif memiliki 12 kabupaten dan 7 wilayah kota. Potensi pengembangan ternak sapi perah sudah dilakukan di 8 kabupaten/kota yakni di Kota Padang Panjang, Kabupaten Tanah Datar, Kota Bukit Tinggi, Kota Payakumbuh, Kabupaten Agam, Kabupaten 50 Kota, Kabupaten Solok Selatan, dan Kabupaten Padang Pariaman. Secara agroklimat Provinsi Sumbar beriklim sedang dengan temperatur $17-27^{\circ} \mathrm{C}$ dengan tingkat curah hujan yang cukup tinggi (Distannak Provinsi Sumatera Barat 2016). Kondisi demikian memungkinkan potensi pengembangan hijauan pakan ternak, yang berdampak positif terhadap pengembangan peternakan terutama ternak sapi perah. Pengembangan sapi perah di Sumbar diarahkan pada 2 wilayah pengembangan yakni dataran rendah dan dataran tinggi dengan berbagai pertimbangan menurut grand desain yang direkomendasikan oleh Dinas Peternakan Provinsi. Pengembangan peternakan sapi perah pada tahun 2015 telah dilakukan di kawasan berdasarkan sumber anggaran yakni pendanaan reguler (1 kelompok), dana APBNP (5 kelompok, 1 UPTD), dan dana TP (1 kelompok). Jumlah ternak melalui pengadaan reguler: 8 ekor betina, APBNP: 100 ekor betina, dan Dana TP: 19 ekor betina. Dilaporkan oleh pihak provinsi bahwa terdapat 3 kelompok masalah yang dihadapi yakni:

1. Masih rendahnya komitmen peternak untuk menjalankan usaha peternakan sapi perah terutama dalam hal rekording,

2. Membutuhkan modal usaha yang tidak sedikit meliputi sarana dan prasarana, pakan hijauan/konsentrat,

3. Produksi susu yang masih relatif rendah, serta

4. Tingkat kematian pedet yang masih dinyatakan tinggi.

Berdasarkan sebaran populasi ternak sapi perah di Provinsi Sumbar, Kota Padang Panjang adalah merupakan lokasi populasi sapi perah tertinggi dibandingkan dengan wilayah kabupaten/kota lainnya (Tabel 2). Berdasarkan populasi dan produksi susu sapi perah di Kota Padang Panjang terlihat bahwa populasi cukup berfluktuasi dari tahun ke tahun. Hal ini merupakan salah satu masalah pengembangan. 
Tabel 2. Populasi dan produksi susu sapi perah di Kota Padang Panjang pada peternakan rakyat (tahun 2010-2013)

\begin{tabular}{lcc}
\hline \hline Tahun & Jumlah (ekor) & Produksi susu (ton/tahun) \\
\hline 2010 & 343 & 250,95 \\
2011 & 281 & 254,65 \\
2012 & 349 & 533,97 \\
2013 & 247 & 246,28 \\
2014 & 292 & 294,74 \\
2015 & 406 & 621,18 \\
\hline
\end{tabular}

Jumlah populasi sangat berpengaruh terhadap tingkat produksi susu tahunan yang berfluktuasi. Pada tahun 2011 dan 2013 cenderung mengalami penurunan yang cukup tajam. Hal demikian patut direkomendasikan untuk membuat suatu kebijakan dari pihak pemerintah daerah, sehingga penurunan populasi ternak tidak terjadi. Kondisi demikian diperlukan solusi dalam hal memecahkan permasalahan tersebut sehingga proses pengembangan peternakan sapi perah melalui berbagai upaya yang terintegratif lintas institusi termasuk pemerintah pusat dalam upaya mendukung swasembada susu nasional dapat tercapai.

Pada tahun 2014-2015 populasi mengalami peningkatan karena adanya program pengembangan baik oleh pemerintah provinsi maupuan kebijakan Kota Padang Panjang sendiri sehingga produksi susu meningkat tajam yakni mencapai 294,74 ton dan 621,18 ton masing-masing pada tahun 2014 dan 2015. Peningkatan produksi susu di wilayah ini juga perlu dipacu, karena kondisi wilayah yang sangat cocok untuk pengembangan sapi perah ditinjau dari ketinggian tempat yang terkait dengan iklim yang sejuk yang potensial untuk habitas pengembangan sapi perah. Upaya yang dilakukan dalam pengembangan di lokasi yang sudah dilakukan oleh pihak pemerintah pusat, provinsi dan Kota Padang Panjang sendiri meliputi: (a) Program pembibitan; (b) Pelayanan Inseminasi Buatan; (c) Peningkatan SDM, dan (d) Monitoring dan evaluasi (monev).

\section{Hasil analisis agro-ekosistem lokasi penelitian}

Lokasi yang dilakukan kajian analisis agro-ekosistem adalah di Kelurahan Kampung Manggis, Kecamatan Padang Panjang Barat. Pemilihan ini berdasarkan pertimbangan bahwa di lokasi tersebut mampu sebagai wilayah percontohan pengembangan sapi perah dengan kondisi kelompok yang cukup bagus dan didukung adanya pakan berupa hijauan yang selalu tersedia sepanjang waktu. Oleh karena itu, diperlukan pemetaan wilayah sampling untuk analisis potensi wilayah terpilih di lokasi yang bersangkutan.

\section{Hasil analisis pola ruang}

Lokasi Kelurahan Kampung Manggis, Kecamatan Padang Panjang Barat, Kota Padang Panjang. merupakan lokasi pengembangan sapi perah yang dikelola oleh kelompok dari Dinas Peternakan Provinsi yang dicanangkan sebagai wilayah pengembangan. Wilayah tersebut merupakan areal dataran tinggi dengan kawasan pegunungan yang cukup sejuk dengan potensi sumber hijauan (pakan ternak) yang tersedia yakni berupa rumput lapangan maupun rumput unggul yang ditanam oleh peternak sendiri. Wilayah tersebut berbatasan dengan hutan lindung yang merupakan kawasan kelurahan yang masih asli, dan kedepan dicanangkan sebagai areal pariwisata pegunungan. 
Dari gambaran biofisik wilayah sapi perah (analisis transek biofisik) (Gambar 1), terlihat bahwa topografi lahan di Kelurahan Kampung Manggis adalah merupakan areal perbukitan yang dikelilingi oleh areal hutan lindung yang merupakan tanah hak ulayat (milik nagari). Sedangkan yang ditengah adalah merupakan areal dataran rendah yang dihuni oleh masyarakat untuk melakukan budidaya pertanian termasuk usaha kelompok peternakan sapi perah. Ketinggian tempat berkisar 400-850 m dari permukaan laut (dpl). Sedangkan areal pemukiman penduduk terletak pada ketinggian antara 400-600 m dpl. Tanaman yang diusahakan adalah tanaman pangan dan sayuran maupun tanaman tahunan.

Usaha tani yang dilakukan penduduk adalah padi, palawija, kayu manis, sayuran, sedangkan usaha lainnya yang berdekatan dengan kelompok ternak sapi perah adalah usaha tani tanaman tahunan (durian dan kayu manis) yang merupakan usaha lainnya disamping usaha ternak sapi perah. Permasalahan yang dialami pada kondisi daerah kawasan penduduk adalah adanya erosi lahan, dan sering terjadinya banjir dari areal atas pegunungan. Keberadaan air tersedia dari kawasan pegunungan yang tersedia sepanjang tahun. Hutan yang ada adalah merupakan hutan lindung yang masih merupakan "lahan hak ulayat" yang sering terjadi perebutan pemanfaatan oleh masyarakat disekitar kawasan tersebut. Direncanakan oleh pihak kelurahan setempat akan dipersiapkan sebagai kawasan pariwisata hutan lindung, tetapi realisasinya masih terbentur pada hak ulayat yang ada dilokasi.

\begin{tabular}{|l|l|l|l|l|}
\hline \multicolumn{1}{|c|}{ Selatan } \\
Peubah
\end{tabular}

Gambar 1. Transek biofisik Kelurahan Kampung Manggis, Kecamatan Padang Panjang Barat, Kota Padang Panjang (Sumatera Barat)

\section{Hasil analisis pola waktu (kalender musim pola tanam) di kawasan pengembangan sapi perah}

Dilihat dari kalender pola tanam di lokasi pengamatan menunjukkan bahwa, pola tanam usaha padi sawah tadah hujan yang dilakukan pada saat turun hujan yakni bulan 
November, karena lokasi merupakan areal sawah tadah hujan (dataran sedang - tinggi). Padi yang ditanam adalah padi unggul dengan masa panen selama 3 bulan, yang ditanam 2 kali setahun (IP 200) yang kemudian baru diberakan (tidak bisa ditanami). Pada lahan irigasi kecil juga ada yang dilakukan penanaman padi yang dilanjutkan dengan tanaman cabe, serta sayuran (kubis, lobak, dan tomat). Pada waktu lahan kering, sebagian besar masyarakat menanam sayuran (cabe) yang dilanjutkan dengan tanaman sayuran (kol, lobak, tomat dan lainnya), yang merupakan sumber pendapatan masyarakat Kelurahan Kampung Manggis (Gambar 2).

Pada lahan tidur umumnya ditanami tanaman tahunan yakni kayu manis, dan tanaman hutan, sedangkan pada kondisi lahan pekarangan yang dimiliki oleh masyarakat yang cukup luas ditanam tanaman coklat, sirsak, durian, dan buah-buahan. Dilihat dari ketersediaan rumput untuk pakan ternak sapi perah terlihat ada kecukupan sepanjang tahun yang didukung adanya rumput lapangan yang berasal dari hutan lindung maupun ladang masyarakat. Sebaliknya keberadaan rumput unggul milik peternak hanya tersedia pada saat terdapat musim hujan, yang saat musim kemarau (Bulan Juli dan Agustus) cenderung tidak tersedia. Pada bulan-bulan tersebut sapi perah hanya diberi rumput lapangan sebagai pakan. Secara umum kebutuhan hijauan untuk pakan sapi perah di lokasi pengamatan tidak mengalami kesulitan karena didukung oleh rumput lapangan yang tersedia sepanjang tahun, yang berasal dari areal kehutanan yang tidak begitu jauh dengan lokasi kandang kelompok.

\begin{tabular}{|c|c|c|c|c|c|c|c|c|c|c|c|}
\hline \multicolumn{12}{|c|}{ Bulan } \\
\hline Nov & Des & Jan & FSeb & Mrt & Apr & Mei & Jun & Jul & Ags & Sep & Okt \\
\hline \multicolumn{12}{|c|}{ Lahan irigasi kecil } \\
\hline \multicolumn{3}{|l|}{ Padi } & \multirow{2}{*}{$\begin{array}{l}\text { Olah } \\
\text { lahan }\end{array}$} & \multicolumn{3}{|l|}{ Padi } & \multicolumn{5}{|c|}{ Beras } \\
\hline \multicolumn{3}{|l|}{ Padi } & & \multicolumn{3}{|l|}{ Cabe } & \multicolumn{5}{|c|}{ Sayuran (kubis, lobak,tomat) } \\
\hline \multicolumn{12}{|c|}{ Lahan kering } \\
\hline \multicolumn{7}{|c|}{ Cabe } & \multicolumn{5}{|c|}{ Sayuran (kubis, lobak, tomat) } \\
\hline \multicolumn{12}{|c|}{ Lahan tidur } \\
\hline \multicolumn{12}{|c|}{ Kayu manis, tanaman hutan } \\
\hline \multicolumn{12}{|c|}{ Lahan pekarangan } \\
\hline \multicolumn{12}{|c|}{ Coklat, sirsak, durian, buah-buahan } \\
\hline \multicolumn{12}{|c|}{ Persediaan pakan ternak } \\
\hline \multicolumn{12}{|c|}{ Rumput lapangan dari ladang/hutan lindung } \\
\hline \multicolumn{8}{|c|}{ Rumput unggul ditanam peternak } & \multicolumn{2}{|c|}{ Kosong } & \multicolumn{2}{|c|}{ R. Unggul } \\
\hline
\end{tabular}

Gambar 2. Hasil analisis pola tanam di Kelurahan Kampung Manggis, Kecamatan Padang Panjang Barat, Kota Padang Panjang (Sumatera Barat)

\section{Hasil analisis tipologi usaha ternak sapi perah di Kota Padang Panjang}

Tipologi Usaha Tani menggambarkan besaran proporsi pendapatan usaha ternak sapi perah sebagai topik utama penelitian ini, dibandingkan dengan kontribusi usaha lainnya dari total pendapatan peternak sebagai pelaku usaha tani spesifik lokasi. Hasil penelitian menunjukkan bahwa total pendapatan peternak sapi perah di lokasi mancapai Rp. 46.679.599/peternak/tahun, atau Rp. 3.889.665/peternak/bulan. Nilai ini dapat dinyatakan cukup baik pada kondisi pedesaan. Pendapatan usaha tani sayuran adalah yang tertinggi sebagai pendapatan rumah tangga yakni mencapai Rp.14.030.000/peternak/tahun (30,26\%) 
(Tabel 3), yang kemudian disusul pendapatan dari buruh tani yang mencapai Rp. 13.999.998/peternak/tahun (29,99\%). Semakin rendah proporsi usaha ternak maka peran pemerintah akan lebih besar dalam pengembangan usaha yang menjadi topik pengamatan. Proporsi usaha tertinggi pada pendapatan rumah tangga, menunjukkan bahwa usaha tersebut adalah yang paling besar dalam mendukung ekonomi rumah tangga.

Tabel 3. Hasil analisis Tipologi Usaha peternak sapi perah di Kota Padang Panjang

\begin{tabular}{lc}
\hline \hline Usaha tani paternak & Pendapatan usaha $(\mathrm{Rp})$ \\
\hline Sapi perah & 11.543 .233 \\
Tanaman padi & 268.823 \\
Sayuran & 14.030 .000 \\
Kayu manis & 4.758 .000 \\
Buruh tani & 13.999 .998 \\
Dagang (off farm) & 2.079 .545 \\
Total & 46.679 .599 \\
\hline
\end{tabular}

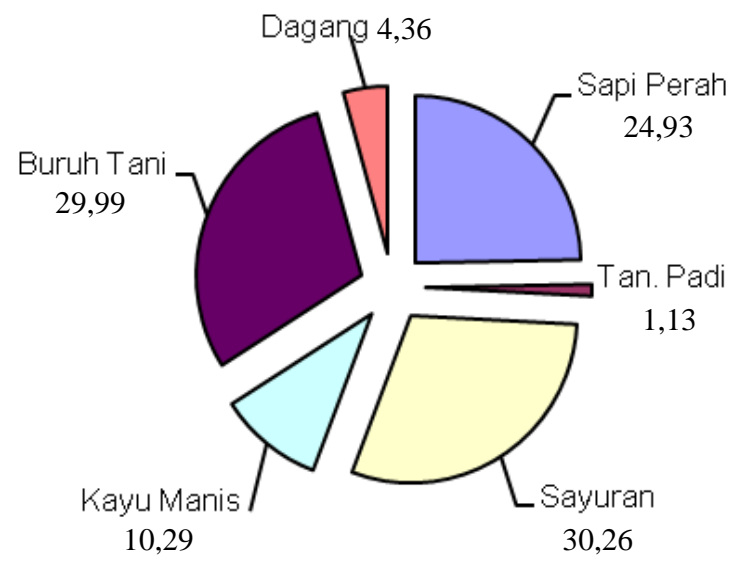

Gambar 3. Proporsi pendapatan peternak sapi perah di Kota Padang Panjang (\%)

\section{Kajian rantai tataniaga pemasaran susu dari peternak ke konsumen akhir di Kota Padang Panjang (kasus wilayah dataran tinggi)}

Hasil pengamatan pemasaran susu segar yang dihasilkan oleh peternak sapi perah di Kota Padang Panjang cukup bervariasi di mana terjadi 4 jalur pemasaran susu yakni meliputi (Gambar 4):

1. Pedagang pengolah susu datang membeli susu ke peternak. Hasil susu dari peternak ada yang langsung dibeli oleh pedagang yang datang ke lokasi peternak, yakni skala kecil (10-15 liter), yang oleh pedagang tersebut diolah menjadi "susu olahan" dengan tambahan coklat, stroberi, es susu dan lainnya yang dijual khususnya untuk anak sekolah ataupun diecerkan pada konsumen.

2. Peternak menjual susu ke Rumah Susu. Di Kota Padang Panjang telah dibangun Rumah Susu oleh Dinas Peternakan Provinsi, yakni semacam "café/restoran" yang terlihat cukup bagus di lokasi strategis di Kota Padang Panjang. Rumah susu tersebut mengolah susu sapi menjadi: es krim, yoghurt, susu pasteurisasi, stik susu (olahan kering lainnya), yang dijual di café. Rumah susu tersebut lengkap dengan perlengkapan mesin pendingin susu, Dokter Hewan yang menganalisis kualitas susu yang disetor peternakuntuk 
mengontrol kualitas susu. Cafe ini dikontrol pula oleh Dinas Peternakan setempat. Kapasitas tampung cafe tersebut masih terbatas yakni hanya 250 1/hari.

3. Peternak menjual susu sapi ke café-café lain. Susu banyak yang dikirim oleh peternak langsung ke café-café yang ada di Kota Padang Panjang, maupun ke Kota Padang yang dibuatkan olahan berupa kopi susu, coklat susu, dan lainnya yang dijual langsung pada langganan yang datang untuk meminum susu. Masalah bagi peternak adalah rendahnya konsumen pada bulan puasa sehingga banyak café yang tutup pada bulan tersebut. Kekosongan permintaan dari café-café tersebut dirasakan peternak mengganggu pemasaran susu.

4. Susu dikirim keluar wilayah. Peternak banyak juga yang memasarkan susu keluar wilayah provinsi yakni ke Provinsi Riau (Pekanbaru) dan Kota Padang yang dikirim melalui travel atau bus yang dititipkan, dan sudah ada konsumen tetap yang mengambil di lokasi sasaran. Hal tersebut karena di Riau dan wilayah lainnya cenderung tidak berkembang usaha sapi perah yang diprogramkan pemerintah, sehingga kebutuhan susu diambil dari Padang Panjang.

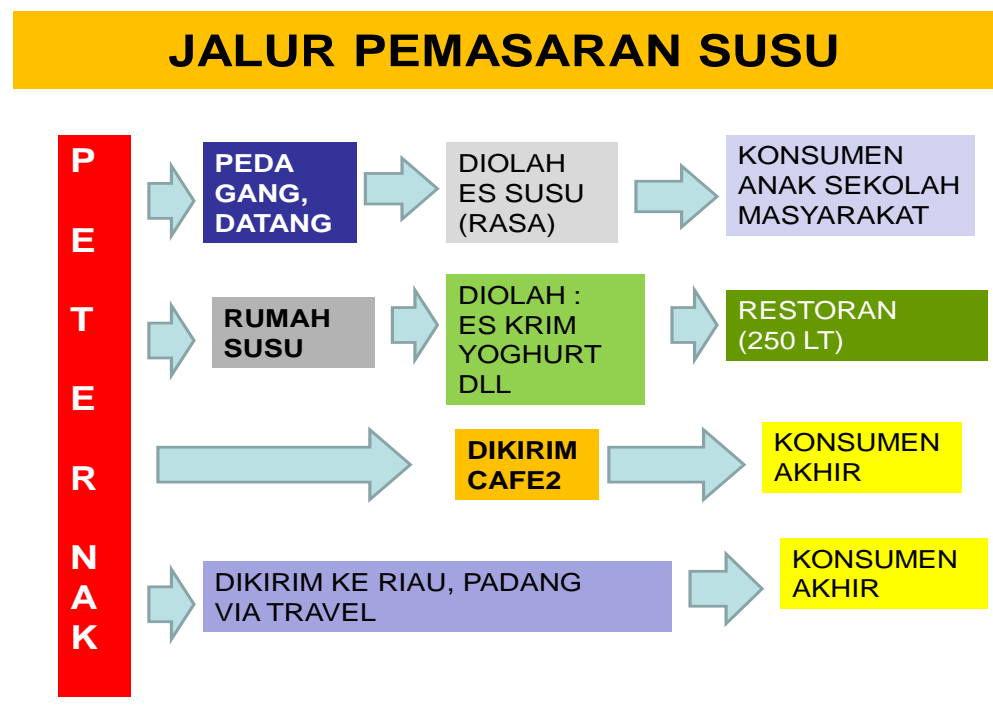

Gambar 4. Jalur pemasaran susu yang dilakukan oleh peternak sapi perah di dataran tinggi Kota Padang Panjang (Sumbar)

Pemasaran susu hasil produksi peternak sapi perah masih banyak mengalami hambatan menurut peternak antara lain:

1. Menurunnya jumlah konsumen susu. Pada bulan puasa banyak susu yang tidak terjual. Hal tersebut karena banyak konsumen yang melakukan ibadah puasa sehingga permintaan susu sangat berkurang jauh dan banyak yang tidak laku terjual (cafe-cafe tutup, dan pasar anak sekolah kurang). Dinyatakan bahwa pada bulan tersebut (1 bulan) banyak susu yang tidak dapat diperdagangkan sehingga diberikan saja pada yang mau mengkonsumsi, bahkan banyak peternak yang membuang susu sapinya. Dinyatakan peternak bahwa pada bulan tersebut sangat merugikan karena biaya operasional usaha tetap padahal tidak ada pemasukan.

2. Belum adanya industri pengolah susu (IPS). Tidak adanya penampung susu yang siap menampung susu sepanjang tahun, karena belum adanya industri pengolahan susu yang ada di lokasi. Susu hanya dikirim pada café-café (sebagian besar), yang cenderung tutup pada pada bulan puasa, sehingga tidak mampu menampung susu hasil peternak sapi perah. 
3. Kapasitas tampung Rumah Susu belum memadai. Sudah ada "Rumah Susu" yang dibuat oleh pemerintah Provinsi Sumbar, tetapi kapasitas tampung hanya mencapai 250 1/hari, sehingga tidak mampu menampung semua produksi susu di Kota Padang Panjang khususnya, maupun Sumatera Barat pada umumnya, karena rumah susu ini juga menampung susu dari wilayah lainnya di sekitar Kota Padang Panjang (di lokasi dataran rendah Kabupaten Padang Pariaman).

Dalam mengantisipasi masalah pemasaran susu tersebut, maka banyak peternak yang membatasi produksi susu sapinya, yang dilakukan dengan cara membatasi pemberian pakan (khususnya konsentrat), sehingga produksi susu cenderung tidak optimal sesuai potensi genetiknya. Hal ini akan memperbesar biaya operasional pemeliharaan (efisiensi usaha tidak dicapai).

\section{KESIMPULAN}

Dari hasil penelitian analisis kinerja pengembangan sapi perah di dataran tinggi Kota Padang Panjang, Provinsi Sumatera Barat, dapat disimpulkan bahwa: pengembangan sapi perah layak dilakukan di lokasi ini karena Agorekosistemnya layak yakni temperatur dingin yang cocok bagi pertumbuhan sapi perah karena Padang Panjang berada di 400-850 $\mathrm{m}$ dpl. Selain itu, kecukupan sumberdaya lahan yaitu tingginya daya dukung pakan hijauan. Kedua komponen ini menunjukkan prospek positif dalam pengembangan sapi perah. Pakan hijauan pendukung utama adalah rumput lapangan yang bersumber dari lahan kehutanan, sedangkan rumput unggul hanya sebagai tambahan. Tambahan ampas tahu merupakan pakan tambahan utama.

Proporsi sumbangan hasil usaha ternak sapi perah mencapai $24,93 \%$ menduduki urutan ke-3 dari total hasil pendapatan keluarga, setelah usaha tani sayuran, dan sebagai buruh tani. Urutan ini menunjukkan prospek yang baik. Jalur pemasaran susu sudah terbentuk walau masih dengan kapasitas terbatas, yakni dominan dilakukan untuk menyuplai cafe-cafe, pedagang olahan susu, dan dikirim ke wilayah lainnya (Riau, dan Kota Padang), maupun disetor ke Rumah Susu.

Saran agar perkembangan sapi perah ini berlanjut agar IPS yang sudah berkembang baik di Pulau Jawa melebarkan wilayah jangkauannya ke luar Pulau Jawa, antara lain ke Sumatera, sehingga produk susu dapat ditampung setiap waktu, sehingga tidak terjadi kesulitan pemasaran susu oleh peternak.

\section{DAFTAR PUSTAKA}

Amir P, Knipscheer HC. 1989. Conducting on-farm animal research procedure and economic analysis. Morrilton (USA): Winrock International Institute for Agricultural Development and International Development Research Centre.

Conway GR. 1985. Agro-ecosiste, analysis for research and development. Bangkok (Thailand): Winrock International.

Deny S. 2014. 80\% Kebutuhan Susu Nasional Masih Impor. Liputan6.com (http:/me.liputan6.com/septiandeny).

Distannak Provinsi Sumatera Barat. 2016. Laporan tahunan. Padang Panjang (Indonesia): Dinas Pertanian dan Peternakan Provinsi Sumatera Barat.

Ditjen Peternakan. 2006. Statistik Peternakan. Jakarta Padang Panjang (Indonesia): Direktorat Jenderal Peternakan 2006. 
Ditjen PKH. 2015. Statistik Peternakan. Jakarta (Indonesia): Direktorat Jenderal Peterbnakan dan Kesehatan Hewan.

Gibbs C. 1985. Rapid Rural Appraisal: An overview of concepts an application. Paper presented in the International Conference on Rapid Rural Appraisal, September 2-5, 1985. Khon Kaen, Thailand.

Gayatri S, Setiadi A, Isbandi, Budihardjo. 2005. Analisis ekonomi pemberian kredit sapi perah di Kecamatan Pakem, Kabupaten Sleman, Yogyakarta. Dalam: Mathius IW, Bahri S, Tarmudji, Prasetyo LH, Triwulanningsih E, Tiesnamurti B, Sendow I, Suhardono, penyunting. Inovasi teknologi peternakan untuk meningkatkan kesejahteraan masyarakat dalam mewujudkan kemandirian dan ketahanan pangan nasional. Prosiding Seminar Nasional Teknologi Peternakan dan Veteriner. Bogor, 12-13 September 2005. Bogor (Indonesia): Puslitbangnak. hlm.

Majalah Tani Merdeka. 2008. Masih Mengandalkan Susu Impor. [Internet]. Available at http://www.tanimerdeka.com/modules.php?name=News\&file=article \&sid=184.

Pambudi R, Sipayung T, Priatna WB, Burhanuddin, Kriswantriyono A, Satria A. 2001. Kumpulan Pemikiran. Bisnis dan kewirausahaan dalam sistem agribisnis. Cetakan ketiga (edisi revisi). Bogor (Indonesia): Pastaka Wirausaha Muda.

Sa'id EG, Intan AH. 2001. Manajemen agribisnis. Jakarta (Indonesia): PT Ghalia Indonesia dengan MMA - IPB.

Saragih B. 2001. Kumpulan Pemikiran. Agribisnis. Paradigma Baru Pembangunan Ekonomi Berbasis Pertanian. Jakarta (Indonesia): Yayasan Mulia Persada Indonesia dan PT Suveyor Indonesia bekerja sama dengan Pusat Studi Pembangunanan IPB dan Unit for Sosial and Economic Studies and Evaluation (USESE) foundation.

Soehadji. 1992. Pembangunan peternakan dalam pembangunan jangka panjang tahap II. Prosiding. Agro Industri Peternakan di Pedesaan. Bogor (Indonesia): Pusat penelitian dan Pengembangan Peternakan.

Tempo. 2016. Indonesia dikhawatirkan impor susu pada 2021. [Internet]. Available at https://m.tempo.co/read/news/2016/04/27/090766195/indonesia-dikhawatirkan-impor-susupada 2021.

\section{DISKUSI}

\section{Pertanyaan}

Bagaimana harga susu di tingkat peternak yang ada di lokasi penelitian?

\section{Jawaban}

Harga susu tinggi dikarenakan untuk memenuhi kebutuhan di restoran dan café. 